\title{
The preliminary ethnobotanical survey of medicinal plants in Develi (Kayseri/Turkey)
}

\author{
Zeynep Büșra Erarslan' (D), Rıdvan Çolak ${ }^{1}$, Șükran Kültür ${ }^{1}$ (i) \\ 'İstanbul University, Faculty of Pharmacy, Department of Pharmaceutical Botany, İstanbul, Turkey
}

ORCID IDs of the authors: Z.B.E.0000-0001-7541-2569; R.Ç. 0000-0003-3929-2007; Ș.K.0000-0001-9413-5210

Cite this article as: Erarslan, Z. B., Colak, R., \& Kültür, S. (2021). The preliminary ethnobotanical survey of medicinal plants in Develi (Kayseri/Turkey). Istanbul Journal of Pharmacy, 51(2), 263-270.

\begin{abstract}
Background and Aims: In Turkey, there is a growing interest in ethnobotany due to the wealth of biological and cultural diversity. The main purpose of this study is to record and highlight the medicinal plants used therapeutically in the Develi district.

Methods: The data were obtained during different seasons of 2010-2011 through face-to-face interviews. Medicinal plants were collected with the guidance of the informants, and traditional uses was recorded. Botanical identification of all the species was made, and voucher specimens were deposited at Istanbul University, Herbarium of the Faculty of Pharmacy (ISTE). Results: The informants reported data on 14 medicinal plants belonging to 8 botanical families. These medicinal plants are used for about 26 different purposes. The most dominant family is Lamiaceae (6 species) followed by Asteraceae ( 2 species). Various plant parts such as leaf, fruit, flower, root, wood and fruity branch are used; the aerial part is consumed more frequently than other plant parts.

Conclusion: Despite the modernization and cultural change, many people still benefit from the plants distributed in the Develi district. This study offers valuable information on the traditional knowledge of medicinal plants, which could form a basis for future phytochemical and pharmacological researches.
\end{abstract}

Keywords: Develi, ethnobotany, Kayseri, medicinal plants, Turkey

\section{INTRODUCTION}

Turkey has a rich flora with over 11000 taxa, approximately 34\% of these are endemic. Our country gets ahead of all European countries in terms of the number of endemic plants (Güner et al., 2018; Güner, 2014). This floristic richness and cultural heritage from the past constitute a great deal of ethnobotanical knowledge which should be revealed (Yeşilada, 2013; Kendir \& Güvenç, 2010).

As known, many ethnobotanical practices such as making tools or using medicinal plants are generally learned in situ, as children work alongside parents or elder siblings. However, technological developments and modernization change the socio-cultural structure of the society, and it is becoming more difficult to conduct ethnobotanical studies or access to information about ethnobotanical practices. Therefore, ethnobotanical data which is about to disappear attracts scholarly attention and many researchers have begun to document this academic value (Güner, 2014; Yeşilada, 2013; Kendir \& Güvenç, 2010; Cotton, 1996).

In Turkey, ethnobotanical studies have become increasingly recognised as a valuable source of information on the use and conservation of many plants, particularly after the 1980s. Many systematic field studies have begun to record traditional medicine carefully, and thus become an important resource for drug discovery research (Yeşilada, 2013; Baytop, 1999). Throughout recent years, numerous ethnobotanical studies have been published in Turkey concerning the traditional use 
of medicinal plants and many studies have been conducted in Central Anatolia (Sağıroğlu, Topuz, Ceylan, \& Turna, 2013; Gençler Özkan \& Koyuncu, 2005; Sezik et al., 2001; Doğan, Başlar, Ay, \& Mert, 2004; Bağcı, 2000; Ertuğ, 2000).

Kayseri province is located in the central Kızlırmak section of Central Anatolia. Its eastern part is situated in upper Kızılırmak River while the southern part is in the Mediterranean region. General characteristics of the Irano-Turanian vegetation types prevail in this region, these vegetation elements such as Consolida orientalis (J.Gay) Schrödinger, Glaucium flavum Crantz, Fumaria officinalis L., Isatis glauca Aucher, Capsella bursa-pastoris (L.) Medik., Silene conica subsp. subconica (Friv.) Gavioli, Peganum harmala L., Melilotus officinalis (L.) Pall., Cirsium arvense (L.) Scop., Sideritis lanata L., Salvia multicaulis Vahl, Euphorbia orientalis L., Cynodon dactylon (L.) Pers. can be seen in various areas of Kayseri province (Türkmen, 2006). This floral and also cultural richness forms a basis for noteworthy ethnobotanical knowledge. Although there are some prior ethnobotanical studies that have been carried out in various regions of Kayseri (Sağıroğlu et al., 2013; Gençler Özkan \& Koyuncu, 2005; Sezik et al., 2001; Bağcı, 2000), traditional uses of medicinal plant in the Develi district have not been reported. The aim of the present study is to provide information about the ethnobotanical properties of medicinal plants which are used traditionally by the local people of the Develi district.

\section{MATERIAL AND METHODS}

\section{Study area}

Develi, which is one of the biggest districts of Kayseri, is situated in the central part of Turkey. Develi was established $6 \mathrm{~km}$

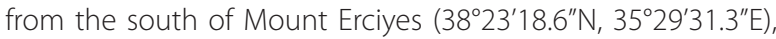
is surrounded by Tomarza District and Tufanbeyli District of Adana Province in the east, Yahyalı District and Saimbeyli-Feke Districts of Adana Province in the south, Yeşilhisar District in the west and Incesu District in the northwest (Figure 1). Develi

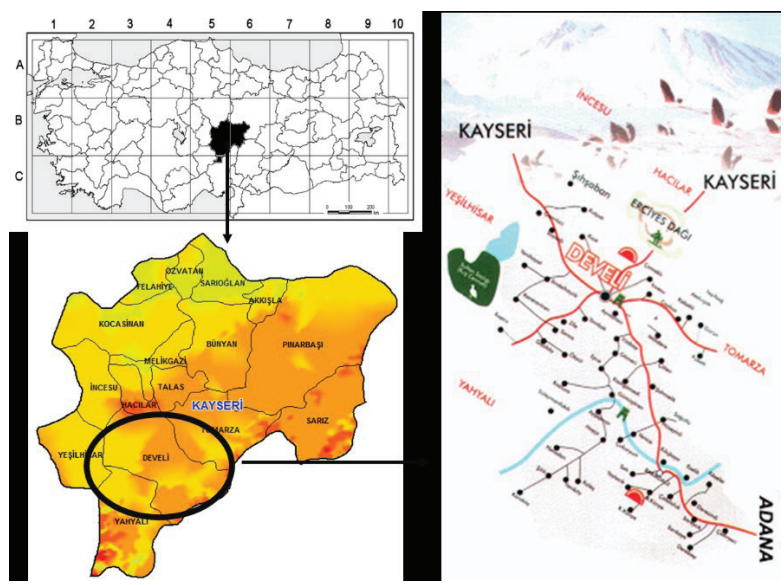

Figure 1. The geographical location of the study area.

is included in Irano-Turanian flora region and falls within the B5 grid square according to the Grid classification system used in the Flora of Turkey (Davis et al., 1988; Davis, 1965-1985).
The surface area of the district is $1887 \mathrm{~km}^{2}$, and the altitude of the central district is $1150 \mathrm{~m}$ above sea level. The total population is 65,745 according to the population census in 2019. The most important mountains of the region are Erciyes Mountain, Karasivri Mountain, Büyük Kartın (Peri Kartın), Göktepe, Sümengen (Süvegen) and Bakır Mountain. The reedfield Sultan Sazlığı, which is located at the lowest part of the Develi plain, contains important floral and faunal communities. Develi is one of the least precipitation areas of our country. The average annual rainfall varies between 300 and $500 \mathrm{~mm}$, and it usually falls in spring. The annual average temperature is calculated as $10.6^{\circ} \mathrm{C}$. Develi has hosted various civilizations for centuries. Although the first settlement date could not exactly be determined, some ruins of the Hittite period were found in the region. After the domination of Phrygians, Persians and Seljuks, the district passed to the Ottoman administration in 1474. Develi was accepted as the district of Kozan province until 1926. When the status of Kozan changed, Develi became Kayseri district (Türkmen, 2006).

\section{Data collection, plant materials}

A field study was carried out during different seasons of 20102011 in the Develi district of Kayseri. After the local people were informed about the study, face-to-face interviews were held in order to document ethnobotanical knowledge. Related data were obtained from local people by using interview questions including information on local plant names, ailments and diseases treated, therapeutic effects, parts of plants used. All plant specimens were collected together with accompanied informants. Plant specimens were numbered and pressed in the field (Figures 2-5).

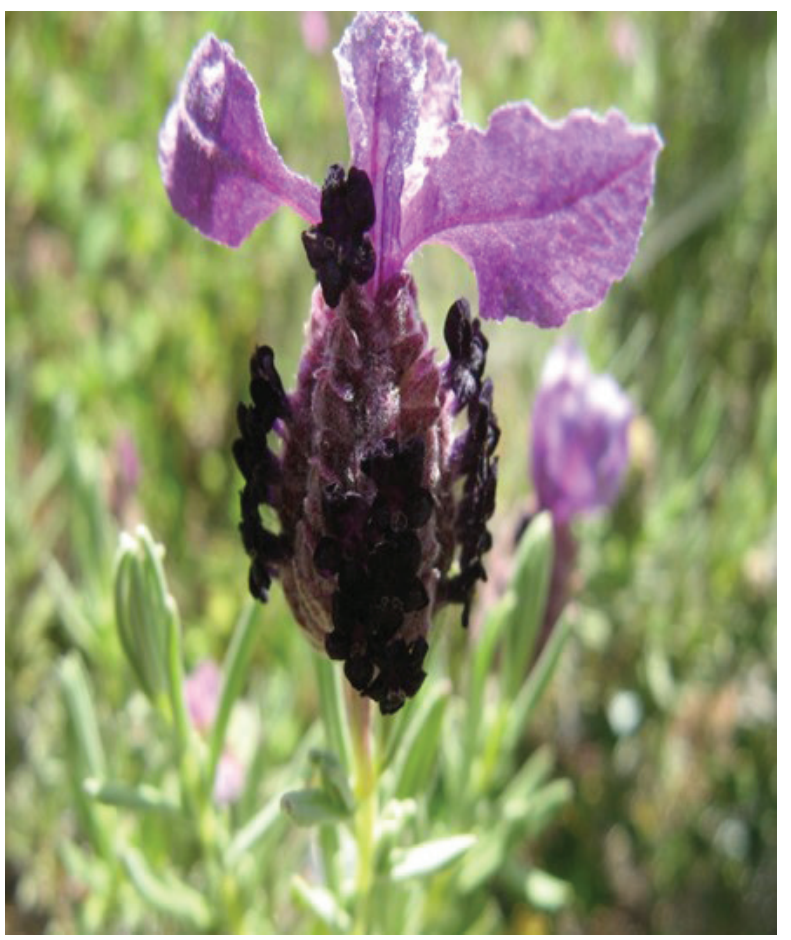

Figure 2. Lavandula stoechas L. 


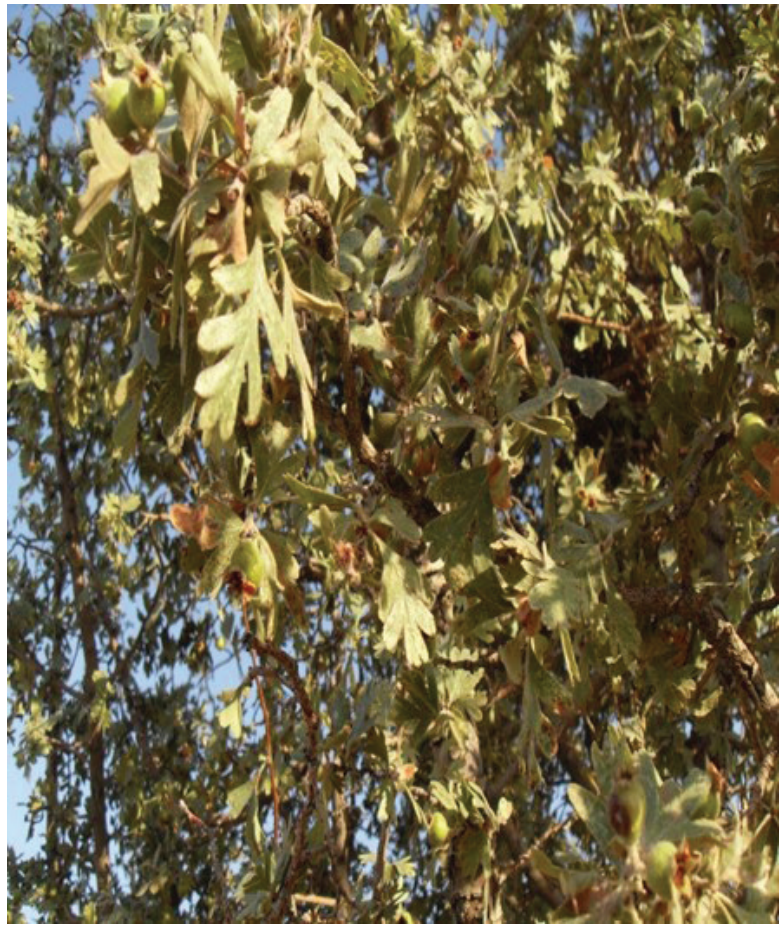

Figure 3. Crataegus meyeri Pojark.

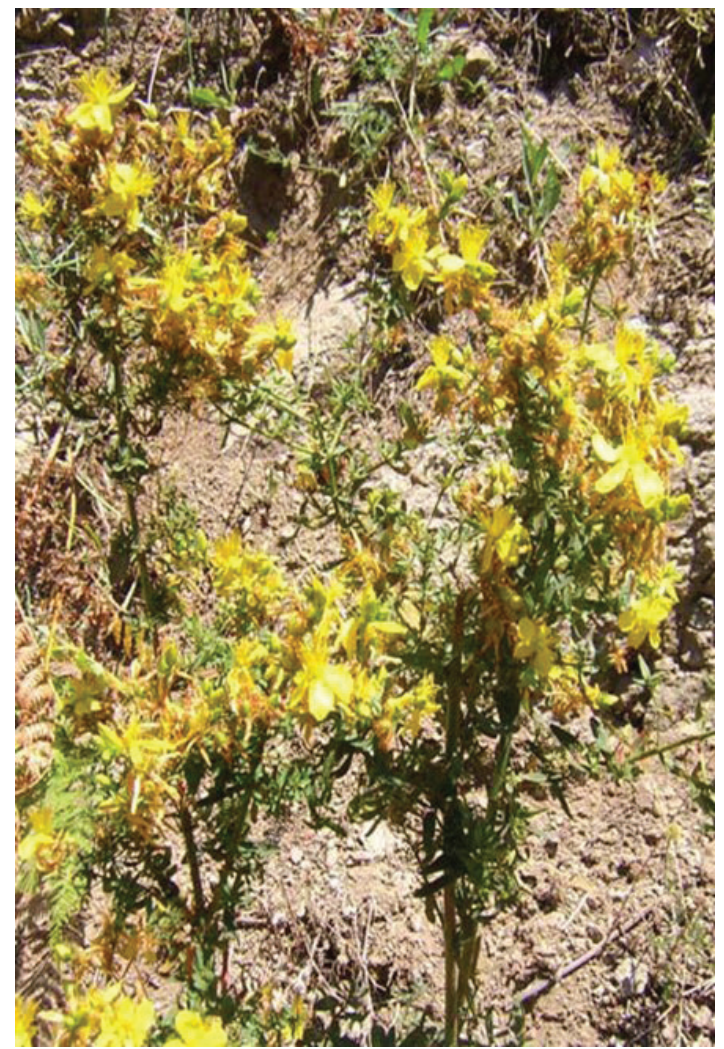

Figure 4. Hypericum perforatum L.

Collected plant specimens were identified by two of the authors (Rıdvan Çolak, Şükran Kültür) using references, i.e. Flora of Turkey and the East Aegean Islands (Davis, 1965-1985; Davis, Mill, \& Tan, 1988; Güner et al., 2000) and Türkçe Bitki Adları

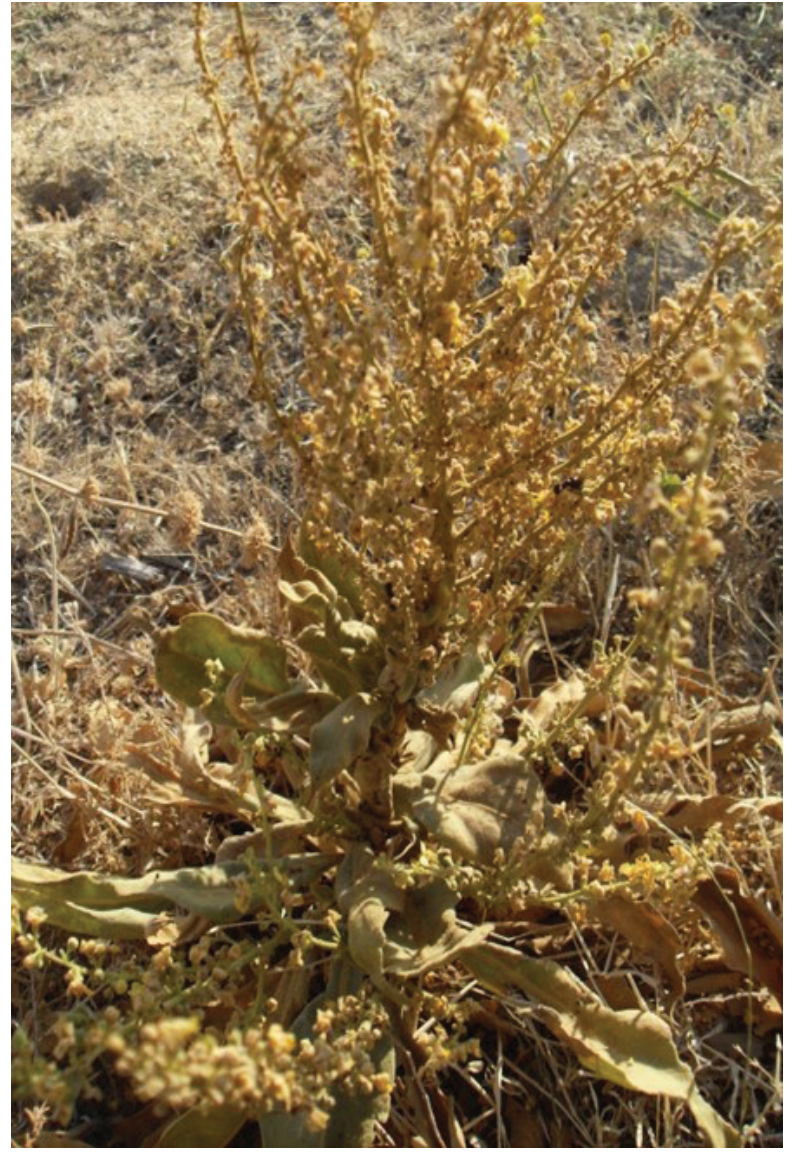

Figure 5. Verbascum sp.

Sözlüğü (Baytop, 1994), and compared with specimens stored in Istanbul University, Herbarium of the Faculty of Pharmacy (ISTE). The voucher specimens were deposited in the ISTE Herbarium. The names of plant families were listed in alphabetical order. Scientific names of identified taxa were updated according to The Plant List (http://www.theplantlist.org/). Ethnobotanical data were screened to reveal whether the plants used have literature records or not.

\section{RESULT AND DISCUSSION}

A total of 14 plant species with ethnobotanical importance belonging to 8 botanical families were found out and documented in this research. Each species is presented with its corresponding botanical identity, herbarium sample number, family name, vernacular name, part used and ethnobotanical usage.

\section{Alcea pallida (Willd.) Waldst. \& Kit., R. Celik 08, Malvaceae} Vernacular name: Gülhatmi, Gülfatma

\section{Used parts: Leaves, roots}

Ailments treated/Therapeutic effect: Asthma, cough, expectorant, diuretic (leaves)

Previous ethnobotanical literature records: Cough (Kurnaz Karagöz \& Serteser, 2017; Tetik, Civelek, \& Cakılcıoğlu, 2013; Demirci \& Özhatay, 2012; Keskin, 2011; Saday, 2009; Karataş, 2007; Bağcı, 2000), bronchitis (Tetik et al., 2013; Saday, 2009; Demirci \& Özhatay, 2012), stomach diseases (Bağcl, 2000), 
ophthalmia (Sağıroğlu et al., 2013), toothache (Sağıroğlu et al., 2013), ornamental plant (Keskin, 2011), respiratory disorders (Kurnaz Karagöz \& Serteser, 2017; Keskin, 2011; Karataş, 2007), gingivitis (Oral, 2007), painkiller, kidney stone (Karataş, 2007), smoothing throat (Keskin, 2011)

\section{Ajuga chamaepitys subsp. laevigata (Boiss.) P.H.Davis, R. Celik 05, Lamiaceae}

Vernacular name: Karın ağrısı otu, Bodur otu

Used parts: Aerial parts

Ailments treated/Therapeutic effect: Abdominal pain, severe diarrhea (especially in animals), wound healing

Previous ethnobotanical literature records: Diabetes (Polat \& Çakılcıoğlu, 2018), removing fear, constipation (Kaya, Dağlı, \& Celik, 2020)

\section{Crataegus meyeri Pojark., R. Celik 13, Rosaceae}

Vernacular name: Alıç Used parts: Fruits, wood

Ailments treated/Therapeutic effect: Vasodilator, kidney and urinary tract purification

Previous ethnobotanical literature records: Antidiarrheal (Yeşil \& Akalın, 2009), diabetes (Şenkardeş, 2014; Yeşil \& Akalın, 2009), asthma, hemorrhoids (Tetik et al., 2013), cardiovascular diseases (Şenkardeş, 2014; Gençler Özkan \& Koyuncu, 2005), rheumatism (Gençler Özkan \& Koyuncu, 2005), kidney stone, constipation, foodstuff, fuel, tool (Şenkardeş, 2014)

\section{Echinophora tenuifolia subsp. sibthorpiana (Guss.) Tutin, R. Celik 09, Apiaceae}

Vernacular name: Çörtük, Çörtlük

Used parts: Aerial parts

Ailments treated/Therapeutic effect: Hand, foot and mouth wounds

Previous ethnobotanical literature records: Foodstuff (Şenkardeş, 2014; Ertuğ, 2000), soup, seasoning, drinking (Doğan et al., 2004)

\section{Echinops ritro L., R. Celik 14, Asteraceae}

Vernacular name: Deve dikeni

Used parts: Aerial parts

Ailments treated/Therapeutic effect: Stomachache

Previous ethnobotanical literature records: Foodstuff (Güneş, Savran, Paksoy, Koşar, \& Çakılcıoğlu, 2018; Özüdoğru, Akaydın, Erik, \& Yeşilada, 2011), fodder (Ertuğ, 2000), stomach complaints (Özüdoğru et al., 2011)

\section{Helichrysum plicatum DC., R. Celik 06, Asteraceae}

Vernacular name: Altın otu

Used parts: Aerial parts

Ailments treated/Therapeutic effect: Intestinal inflammation, hemorrhoid

Previous ethnobotanical literature records: Cholesterol management, cancer (Güneş, Savran, Paksoy, Koşar, \& Çakılcıŏlu, 2017), kidney and stomach ailments, depreciatory (Yeşil \& Akalın, 2009), kidney stones (Demirci \& Özhatay, 2012; Yeşilada et al., 1995; Yeşilada et al., 1993), diarrhea, abdominal pain, diabetes (Özdemir \& Alpınar, 2015), hypertension, hypercholes- terolemia (Kocabaş \& Gedik, 2016), nephralgia (Sargın, 2015), stomach ulcer, diuretic (Özüdoğru et al., 2011), wound (Sezik et al., 2001; Tetik et al., 2013), ear ache (for baby) (Demirci \& Özhatay, 2012), jaundice, dysuria, snake repellent (Yeşilada et al., 1995), antifungal, urinary dysfunction (Karaman \& Kocabaş, 2001), constipation (Çömlekçioğlu \& Karaman, 2008)

\section{Hypericum perforatum L., R. Celik 12, Hypericaceae}

Vernacular name: Sarı kantaron

Used parts: Aerial parts, flowers

Ailments treated/Therapeutic effect: Rheumatic pain, stomachache, kidney inflammation

Previous ethnobotanical literature records: Ulcers, allergies (Özüdoğru et al., 2011), burn, wound (Sargın \& Büyükcengiz, 2018; Sargın, Selvi, \& Buyukcengiz, 2015; Yeşilada et al., 1993), gastric ulcer, antibiotic, immune system booster (Sargın \& Büyükcengiz, 2018), hemorrhoids (Han \& Bulut, 2015; Akaydın, Şimşek, Arıtuluk, \& Yeşilada, 2013), constipation, prostatitis, diabetes, hypertension, urinary infections, diaper rash, rheumatism, osteoporosis (Akaydın et al., 2013), stomachic, scorch cure (Demirci \& Özhatay, 2012), analgesic, gastrointestinal pains, depression (Sargın, 2015), pyrosis, reflux (Sargın et al., 2015), diarrhea, colic (Özdemir \& Alpınar, 2015, rheumatic pains, nervous disorders (Kocabaş \& Gedik, 2016), sedative, foodstuff, fuel, dye (Akan \& Bakır Sade, 2015), stomachache (Yeşilada et al., 1995; Yeşilada et al., 1993), cardiovascular diseases (Tuzlacı \& Şenkardeş, 2011), spazmolytic, antiseptic, hepatitis, hemostatic, vulnerary, cholagogue, hepatoprotector, anti inflammatory, orexigenic, digestive (Everest \& Öztürk, 2005), gastric diseases, muscle relaxant rheumatism, gastric pain (Uzun \& Kaya, 2016), tonsillit, diuretic, expectorant, shortness of breath (Karataş, 2007), tuberculosis, cold, anthelmintic (Ezer \& Avcl, 2004), relaxation, insomnia (Akgül et al., 2016), gastrointestinal system disorders (Bağcı, Erdoğan, \& Doğu, 2016), contusion and burn, snake bite and scorpion bite (Çömlekçioğlu \& Karaman, 2008), appetizing (Karaman \& Kocabaş, 2001)

\section{Lavandula stoechas L., R. Celik 03, Lamiaceae}

Vernacular name: Karabaş otu

Used parts: Aerial parts, flowers

Ailments treated/Therapeutic effect: Headaches, smoking cessation (as an aid)

Previous ethnobotanical literature records: Cancer (Sargın \& Büyükcengiz, 2018; Akan \& Bakır Sade, 2015), sedative (Sargın \& Büyükcengiz, 2018), pains, smoking cessation (Akan \& Bakır Sade, 2015; Sargın, 2015), cardiovascular disease (Güneş et al., 2017; Sargın, 2015; Çömlekçioğlu \& Karaman, 2008), vasodilator, asthma, bronchitis, headache, brain diseases, ulcer, hypertension, insomnia (Sargın, 2015), stomachache (Güneş et al., 2017; Abay \& Kılıç, 2001), analgesic (Sargın et al., 2015), epilepsy, nervosity, anodyne, stethalgia, blood stimulant, hypertension, throat disorders, digestive, obesity (Everest \& Öztürk, 2005), nervous disorders (Abay \& Kılıç, 2001), hypercholesterolemia (Çömlekçioğlu \& Karaman, 2008)

\section{Marrubium anisodon K.Koch, R. Celik 07, Lamiaceae}

Vernacular name: Elbir otu

Used parts: Aerial parts 
Ailments treated/Therapeutic effect: Kidney stones, female infertility, regulates the blood pressure

Previous ethnobotanical literature records: Not reported.

\section{Melissa officinalis L., R. Celik 01, Lamiaceae}

Vernacular name: Melisa, Oğul otu

Used parts: Leaves

Ailments treated/Therapeutic effect: Cough, asthma, sedative Previous ethnobotanical literature records: Arteriosclerosis (Paksoy, Selvi, \& Savran, 2015), sedative, stress, vasodilator, soporific, female sterility (Sargın, 2015), headache, cardiovascular diseases (Demirci \& Özhatay, 2012), insomnia, scorpion bite, bath, heart palpitation (Akan \& Bakır Sade, 2015), tranquillizer, antidepressant, anhypnia, gastrit, angiemphraxis, epilepsy, fainting, allergy, digestive, cardiotonic, hearth stimulant, carminative, spasmolytic, diaphoretic, disinfectant (Everest \& Öztürk, 2005), cholesterol, hypertension (Oral, 2007), foodstuff (Koçak \& Özhatay, 2013), anemia, diabetes, memory (Akgül et al., 2016), thyroid, sleep disturbances, stress, digestion system (Saltan \& Özaydın, 2013), antiseptic, cold (Karaman \& Kocabaş, 2001)

\section{Peganum harmala L., R. Celik 11, Nitrariaceae}

Vernacular name: Yüzellik, Güzellik otu

Used parts: Fruity branches, fruits

Ailments treated/Therapeutic effect: Protect against the evil eye, allergic asthma

Previous ethnobotanical literature records: Amulet (Özüdoğru et al., 2011), sedative, hemorrhoids, vermifuge, menstrual diuretic (Özdemir \& Alpınar, 2015), evil eye, ornaments (Öztürk, 2004), expectorant, stimulating nervous system, hair loss, eczema, malaria, dye (Akan \& Bakır Sade, 2015), Parkinson, insomnia (Yaşar, Koyuncu, Turan Koyuncu, \& Kuş, 2019; Akan \& Bakır Sade, 2015), emmenagogue, narcotic, sedative, nutritive, cephalalgia, anti hysteria, notalgia, ophthalmalgia, omalgia, hand-tremble (Everest \& Öztürk, 2005), anthelmintic, stomachache (Tugay et al., 2005), headache, hypertension, carminative (for babies) (Oral, 2007), shortness of breath, stomach ulcer, hair dandruff, hair care (Şenkardeş, 2014), foodstuff (Hakverdi \& Yiğit, 2017); dermal diseases (Vural, Karavelioğulları, \& Polat, 1997).

\section{Sideritis libanotica subsp. linearis (Benth.) Bornm., R. Ce-} lik 04, Lamiaceae

Vernacular name: Dağ çayı

Used parts: Aerial parts

Ailments treated/Therapeutic effect: Smoothing throat, vasodilator, diabetes

Previous ethnobotanical literature records: Cold (Demirci \& Özhatay, 2012; Yeşil \& Akalın, 2009), flu (Demirci \& Özhatay, 2012), as a tonic (Yeşilada et al., 1993), foodstuff (Doğan et al., 2004), throat and flu infections (Oral, 2007)

\section{Teucrium chamaedrys subsp. syspirense (K.Koch) Rech.f., R. Celik 02, Lamiaceae}

Vernacular name: Kısamahmut otu

Used parts: Aerial parts

Ailments treated/Therapeutic effect: Hemorrhoid, intestinal fungal infections, antidote

Previous ethnobotanical literature records: Diabetes (Dalar, 2018), foodstuff (as tea) (Aksakal \& Kaya, 2008)

\section{Verbascum sp., R. Celik 10, Scrophulariaceae}

Vernacular name: Yalancı sığır kuyruğu

Used parts: Fruits, leaves

Ailments treated/Therapeutic effect: Allergic asthma

Previous ethnobotanical literature records: draining inflammation, cough, pain of abarticulation or broken bones (Akaydın et al., 2013), asthma, expectorant (Sargın \& Büyükcengiz, 2018), pruritus, shortness of breath, hair loss, dyestuff, uterine inflammations (Özüdoğru et al., 2011), urinary inflammations, fissures on hand, abdominal pain (Gençler Özkan \& Koyuncu, 2005), warts (Savran et al., 2008), sinusitis, nepatitis, hemorrhoids (Tuzlacı \& Şenkardeş, 2011), bronchitis (Saday, 2009)

The Lamiaceae family (6 species) is the most commonly used and species-rich family in this study. It is followed by Asteraceae (2 sp.), Hypericaceae (1 taxon), Malvaceae (1 taxon), Rosaceae (1 taxon), Scrophulariaceae (1 taxon), Apiaceae (1 taxon) and Nitrariaceae (1 taxon), by their number of species. Aerial parts were primarily used for ethnobotanical uses by local people. Other used plant parts were found as leaf, fruit, flower, root, wood and fruity branch, respectively (Figure 6). During this study, a total of 26 traditional usages were recorded. Medicinal plants were used for both human and animal health. Ajuga chamaepitys subsp. laevigata (Boiss.) P. H. Davis was not used only in humans but also in animal treatment. Besides the treatment of diseases, people benefited from plants for different purposes. They believed that Peganum harmala L. protects them from the evil eye.

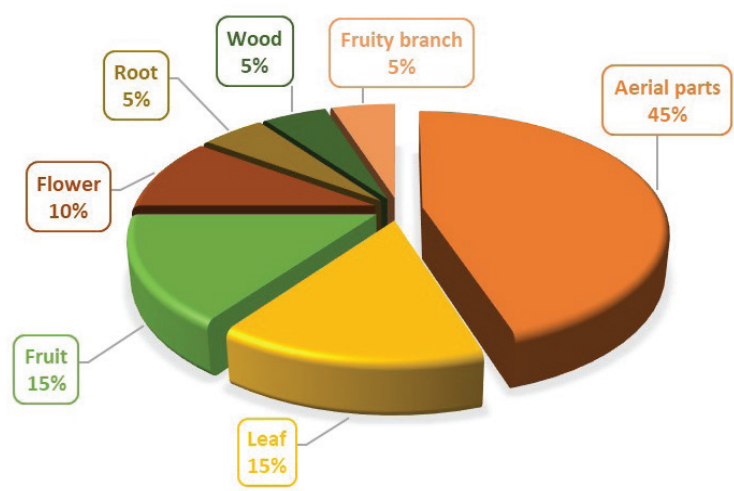

Figure 6. Plant parts used for ethnobotanical purposes ranked by frequency of use.

Recorded traditional uses in the study area were compared with those reported in ethnobotanical studies of Central Anatolia and its environs, and strong affinity was found with the ethnobotanical use. As a result of this comparison, although no medicinal use of Teucrium chamaedrys subsp. syspirense (K.Koch) Rech.f. and Ajuga chamaepitys subsp. laevigata was found, ethnobotanical data from distant regions present several utilizations. T. chamaedrys subsp. syspirense was used for diabetes in Van Province and (Dalar, 2018) Ajuga chamaepitys subsp. laevigata was used for diabetes; removing fear and constipation in Bingöl (Polat \& Çakılcıoğlu, 2018) and Şanlıurfa Provinces (Kaya et al., 2020). Previous ethnobotanical data screening in Turkey revealed that the medicinal use of Marrubium anisodon K.Koch 
was shown for the first time in our study. In addition, some new medicinal uses were found out in this paper: Aerial parts of Ajuga chamaepitys subsp. laevigata for abdominal pain, severe diarrhea (especially in animals) and wound healing; aerial parts of Teucrium chamaedrys subsp. syspirense for hemorrhoid, intestinal fungal infections and as an antidote; fruits and wood of Crataegus meyeri Pojark as vasodilator and for kidney and urinary tract purification; aerial parts of Echinophora tenuifolia subsp. sibthorpiana (Guss.) Tutin for hand, foot and mouth wounds. Comparing this study with the studies from Aladağlar, Yahyalı and Pınarbaşı districts of Kayseri (Sağıroğlu et al., 2013; Gençler Özkan \& Koyuncu, 2005; Bağcı, 2000), Alcea pallida (Willd.) Waldst. \& Kit., Peganum harmala, Crataegus meyeri, Verbascum sp. and Hypericum perforatum L. were detected as five shared taxa used. In addition to similarities in uses, some different uses are also noticeable. For instance, while C. meyeri was used in the treatment of cardiac disorders and rheumatism in Pınarbaşı region (Gençler Özkan \& Koyuncu, 2005), people in the Develi district have benefited from its vasodilator and kidney - urinary tract purification properties.

Some aforementioned medicinal plants contain toxic constituents that adversely affect human health, for this reason, overdose or side effects of these plants can be dangerous according to the literature. Teucrium chamaedrys subsp. syspirense is known as a hepatotoxic plant, therefore, it should not be administered without the recommendation of authority in proper use. Photosensitization of Hypericum perforatum in humans is associated with excessive intake of the plant (Gruenwald et al., 2000). Special attention should be paid to the use of these plants, even though there is no notification from the local people.

\section{CONCLUSION}

The present study documented the traditional uses of 14 plant species belonging to 8 families of medicinal plants by local people. These plants are used either as a remedy for various diseases or for any other purposes in the Develi district of Kayseri. The medicinal uses of Marrubium anisodon were recorded for the first time in this study. It is noteworthy that local people mainly use aerial parts of the plants not underground parts (rhizomes, roots and bulbs). They make contributions to the conservation of the species in the region by preventing the indiscriminate cutting or removing the entire plant.

Since the ethnobotanical knowledge of local plants is mainly possessed by elder family members and transmitted from generation to generation, more studies should focus on compiling as much information as possible before the eventual elimination of traditional knowledge. It is believed that this study provides valuable information on medicinal plants, reinforcing the importance of continuing with ethnobotanical research in Turkey, which can lead to the development of new pharmaceuticals.

Peer-review: Externally peer-reviewed.

Author Contributions: Conception/Design of Study- Z.B.E., R.Ç., Ş.K.; Data Acquisition- Z.B.E., R.Ç., Ş.K.; Data Analysis/Interpretation- Z.B.E., R.Ç., S.K.; Drafting Manuscript- Z.B.E., R.Ç., Ş.K.; Critical Revision of Manuscript- Z.B.E., Ş.K.; Final Approval and Accountability- Z.B.E., R.Ç., Ş.K.
Conflict of Interest: The authors have no conflict of interest to declare.

Financial Disclosure: Authors declared no financial support.

\section{REFERENCES}

- Abay, G., \& Kılıç, A. (2001). Pürenbeleni ve Yanıktepe (Mersin) yörelerindeki bazı bitkilerin yöresel adları ve etnobotanik özellikleri [Local names and ethnobotanical features of some plants in the district of Pürenbeleni and Yanıktepe (Mersin)]. Ot Sistematik Botanik Dergisi, 8(2), 97-104.

- $\quad$ Akan, H., \& Bakır Sade, Y. (2015). Kâhta (Adıyaman) merkezi ve Narince Köyü'nün Etnobotanik Açıdan Araştııılması [Investigation of The etnobotanical aspects the town Kâhta and village of Narince]. Bitlis Eren Üniversitesi Fen Bilimleri Dergisi, 4(2), 219-248.

- $\quad$ Akaydın, G., Şimşek, I., Arıtuluk, Z. C., \& Yeşilada, E. (2013). An ethnobotanical survey in selected towns of the Mediterranean subregion (Turkey). Turkish Journal of Biology, 37, 230-247. https://doi. org/10.3906/biy-1010-139

- $\quad$ Akgül, G., Yılmaz, N., Celep, A., Celep, F., \& Çakılcıoğlu, U. (2016). Ethnobotanical purposes of plants sold by herbalists and folk bazaars in the center of Cappadocica (Nevşehir, Turkey). Indian Journal of Traditional Knowledge, 15(1), 103-108.

- $\quad$ Aksakal, Ö., \& Kaya, Y. (2008, May). Erzurum ve çevresinde halk tarafindan gıda amaçlı olarak kullanılan bitkiler. Türkiye 10. Gıda Kongresi, 1009-1012. Retrieved from http://www.gidadernegi. org/TR/Genel/240934931acdc.pdf?DIL=1\&BELGEANAH=1612\&D OSYAISIM=240934931.pdf

- Bağcı, Y. (2000). Aladağlar (Yahyalı, Kayseri) ve çevresinin etnobotanik özellikleri. Ot Sistematik Botanik Dergisi, 7(1), 89-94.

- Bağcl, Y., Erdoğan, R., \& Doğu, S. (2016). Sarıveliler (Karaman) ve çevresinde yetişen bitkilerin etnobotanik özellikleri [Ethnobotanical features of growing plants in Sarıveliler (Karaman) and its environment]. Selçuk Üniversitesi Fen Fakültesi Fen Dergisi, 42(1), 84-107. Baytop, T. (1994). Türkçe bitki adları sözlüğü. TDK Yayınları, 578.

- Baytop, T. (1999). Türkiye'de bitkiler ile tedavi. (2 ${ }^{\text {nd }}$ ed.). İstanbul, Turkey: Nobel Tıp Kitapevleri Ltd. Şti.

Cotton, C. M. (1996). Ethnobotany: Principles and Applications. London, UK: John Wiley and Sons.

- Çömlekçioğlu, N., \& Karaman, ş. (2008). The Medicinal plants found in the local herbal markets in the city of Kahramanmaras in Turkey. Kahramanmaraş Sütçü Imam Üniversitesi Fen ve Mühendislik Dergisi, 11(1), 23-32.

- Dalar, A. (2018). Plant taxa used in the treatment of diabetes in Van province, Turkey. International Journal of Secondary Metabolite, 5(3), 171-185. https://doi.org/10.21448/ijsm.430703

- Davis, P. H. (1965-1985). The Flora of Turkey and the East Aegean Islands Vol. 1-9, Edinburgh University Press, Edinburgh.

- Davis, P. H., Mill, R. R., \& Tan, K (1988). The Flora of Turkey and the East Aegean Islands Vol. 10, Edinburgh University Press, Edinburgh. Demirci, S., \& Özhatay, N. (2012). An ethnobotanical study in Kahramanmaras (Turkey); wild plants used for medicinal purpose in Andırın, Kahramanmaraş. Turkish Journal of Pharmaceutical Sciences, $9(1), 75-92$.

- Doğan, Y., Başlar, S., Ay, G., \& Mert, H. H. (2004). The use of wild edible plants in western and central Anatolia (Turkey). Economic Botany, 58(4), 684-690.

- $\quad$ Ertug F. (2000). An ethnobotanical study in Central Anatolia (Turkey). Economic Botany, 54(2), 155-182. https://doi.org/10.1007/ BF02907820

Everest, A., \& Öztürk, E. (2005). Focusing on the ethnobotanical uses of plants in Mersin and Adana provinces (Turkey). Journal of Ethnobiology and Ethnomedicine, 1(6), 1-6. https://doi. org/10.1186/1746-4269-1-6 
- $\quad$ Ezer, N., \& Avcı, K. (2004). Çerkeş Çankırı yöresinde kullanılan halk ilaçları. Hacettepe Üniversitesi Eczacılık Fakültesi Dergisi, 24(2), 6780. Retrieved from https://dergipark.org.tr/en/pub/hujpharm/ issue/49861/639238

- Gençler Özkan, A. M., \& Koyuncu, M. (2005). Traditional medicinal plants used in Pınarbaşı area (Kayseri-Turkey). Turkish Journal of Pharmaceutical Sciences, 2(2), 63-82.

- Gruenwald, J., Brendler, T., Jaenicke C., et al. (Eds). (2000). PDR for herbal medicines. ( $2^{\text {nd }}$ ed.). Montvale, NJ: Medical Economics Company.

- Güner, A. (2014). Resimli Türkiye Florası Cilt 1 [lllustrated Flora of Turkey Vol. 1.]. İstanbul, Turkey: Türkiye İş Bankası Kültür Yayınları.

- Güner, A., Kandemir, A., Menemen, Y., Yıldııım, H., Aslan, S., Ekşi, G., Güner, I., \& Çimen, A.Ö. (2018). Resimli Türkiye Florası Cilt 2 [Illustrated Flora of Turkey Vol. 2.] İstanbul, Turkey: ANG Vakfi Nezahat Gökyiğit Botanik Bahçesi Yayınları.

- Güneş, S., Savran, A., Paksoy, M. Y., \& Çakılcıoğlu, U. (2018). Survey of wild food plants for human consumption in Karaisalı (AdanaTurkey). Indian Journal of Traditional Knowledge, 17(2), 290-298.

- Güneş, S., Savran, A., Paksoy, M. Y., Koşar, M., \& Çakılcıoğlu, U. (2017). Ethnopharmacological survey of medicinal plants in Karaisalı and its surrounding (Adana-Turkey). Journal of Herbal Medicine, 8, 68-75. https://doi.org/10.1016/j.hermed.2017.04.002 Hakverdi, A. E., \& Yiğit, N. (2017). Yozgat-Akdağmadeni Yöresinde Bulunan Bazı Tibbi ve Aromatik Bitkiler [Some medicinal aromatic plants in district of Akdağmadeni-Yozgat]. Journal of Bartın Faculty of Forestry, 19(2), 82-87. https://doi.org/10.24011/barofd.341195

- Han, M. I., \& Bulut, G. (2015). The folk-medicinal plants of Kadişehri (Yozgat-Turkey). Acta Societatis Botanicorum Poloniae, 84(2), 237248. https://doi.org/10.5586/asbp.2015.021

- Karaman, Ş., \& Kocabaş, Y.Z. (2001). Traditional medicinal plants of K. Maras (Turkey). The Sciences, 1(3), 125-128. https://doi.org/10.3923/ jms.2001.125.128

- Karataş, H. (2007). Ilgaz (Çankırı) ilçesi ve çevresinin etnobotaniği (Master's thesis, Gazi Üniversitesi, Ankara). Retrieved from https:// www.ulusaltezmerkezi.net/ilgaz-cankiri-ilcesi-ve-cevresinin-etnobotanigi/134/

- Kaya, Ö. F., Dağlı, M., \& Çelik, H. T. (2020). An ethnobotanical research in Şanlıurfa central district and attached villages (Turkey). Indian Journal of Traditional Knowledge, 19(1), 7-23.

- Kendir, G., \& Güvenç, A. (2010). Etnobotanik ve Türkiye'de yapılmış etnobotanik çalışmalara genel bir bakış [Ethnobotany and a general view of ethnobotanical studies in Turkey]. Hacettepe Üniversitesi Eczacılık Fakültesi Dergisi, 30(1), 49-80.

- Keskin, L. (2011). Kadınhanı (Konya) ve çevresinde yetişen bitkilerin etnobotanik özellikleri (Master's thesis, Selçuk Üniversitesi, Konya). Retrieved from https://www.ulusaltezmerkezi.net/kadinhani-konyave-cevresinde-yetisen-bitkilerin-etnobotanik-ozellikleri/25/

- Kocabaş, Y. Z., \& Gedik, O. (2016). Kahramanmaraş il merkezi semt pazarlarında satılan bitkiler hakkında etnobotanik araştırmalar [An Ethnobotanical study of wild plants sold in district bazaar in Kahramanmaras]. Iğdır University Journal of the Institute of Science and Technology Kahramanmaraş, 6(4), 41-50. https://doi. org/10.21597/jist.2016624154

- Koçak, S., \& Özhatay, N. (2013). Wild edible plants in Karaman (Southern Turkey). Journal of Pharmacy of Istanbul University, 43(1), 21-32.

- Kurnaz Karagöz, F., \& Serteser, A. (2017). Evaluation of medical plant diversity in Suşehri and its environment. International Congress on Medicinal and Aromatic Plants, 354-365. https://doi. org/10.1201/b19038-43

- Oral, D. Ç. (2007). Konya ilinde kullanılan halk ilaçları üzerinde etnobotanik araştırmalar (Master's thesis, Gazi Üniversitesi, Ankara). Retrieved from https://www.ulusaltezmerkezi.net/konya-ilindekullanilan-halk-ilaclari-uzerinde-etnobotanik-arastirmalar/
Özdemir, E., \& Alpınar, K. (2015). An ethnobotanical survey of medicinal plants in western part of central Taurus Mountains: Aladaglar (Nigde - Turkey). Journal of Ethnopharmacology, 166, 53-65. https://doi.org/10.1016/j.jep.2015.02.052

Özüdoğru, B., Akaydın, G., Erik, S., \& Yeşilada, E. (2011). Inferences from an ethnobotanical field expedition in the selected locations of Sivas and Yozgat provinces (Turkey). Journal of Ethnopharmacology, 137, 85-98. https://doi.org/10.1016/j.jep.2011.04.050 Paksoy, M. Y., Selvi, S., \& Savran, A. (2015). Ethnopharmacological survey of medicinal plants in Ulukışla (Niğde-Turkey). Journal of Herbal Medicine. https://doi.org/10.1016/j.hermed.2015.04.003

Polat, R., \& Çakılcıoğlu, U. (2018). Ethnobotanical study on medicinal plants in Bingöl (City center) (Turkey). Journal of Herbal Medicine, 6(1), 42-48. https://doi.org/10.1016/j.hermed.2018.01.007

- Saday, H. (2009). Güzeloluk köyü ve çevresinin (Erdemli /Mersin) etnobotanik özellikleri (Master's thesis, Selçuk Üniversitesi, Konya). Retrieved from https://www.ulusaltezmerkezi.net/guzelolukkoyu-ve-cevresinin-erdemlimersin-etnobotanik-ozellikleri/ Sağıroğlu, M., Topuz, T., Ceylan, K., \& Turna, M. (2013). An Ethnobotanical Survey From Yahyalı (Kayseri) And Tarsus (Mersin). Sakarya Üniversitesi Fen Edebiyat Dergisi, 2, 13-37.

- $\quad$ Saltan, F. Z., \& Özaydın, Ö. (2013). Ethnobotany of Eskisehir and its environs. Pakistan Journal of Botany, 45, 207-214.

- Sargın, S. A. (2015). Ethnobotanical survey of medicinal plants in Bozyazı district of Mersin, Turkey. Journal of Ethnopharmacology, 173, 105-126. https://doi.org/10.1016/j.jep.2015.07.009

Sargın, S. A., \& Büyükcengiz, M. (2018). Plants used in Ethnomedicinal practices in Gulnar district of Mersin, Turkey. Journal of Herbal Medicine. https://doi.org/10.1016/j.hermed.2018.06.003

Sargın, S. A., Selvi, S., \& Büyükcengiz, M. (2015). Ethnomedicinal plants of Aydıncık District of Mersin, Turkey. Journal of Ethnopharmacology, 174, 200-216. https://doi.org/10.1016/j.jep.2015.08.008 Savran, A., Bağcı, Y., \& Kargıoğlu, M. (2008). Gemerek (Sivas) ve çevresindeki bazı bitkilerin yerel adları ve etnobotanik özellikleri [Vernacular names and ethnobotanical aspects of some species in Gemerek (Sivas) and its vicinity]. Afyon Kocatepe Üniversitesi Fen Bilimleri Dergisi, 8(1), 313-321.

- Şenkardeş, I. (2014). Nevşehir'in güney ilçelerinde (Acıöl, Derinkuyu, Gülşehir, Nevşehir-Merkez, Ürgüp) etnobotanik araştırmalar in Marmara Üniversitesi (Doctoral dissertation). Retrieved from http://katalog.marmara.edu.tr/veriler/yordambt/ cokluortam/8ADB412F-8874-BC42-A7D7-51D3A541F7E1/ BB1D2CE2-A40B-DC47-AD36-BFC0012EF7FC.pdf

Sezik, E., Yeşilada, E., Honda, G., Takaishi, Y., Takeda, Y., \& Tanaka, T. (2001). Traditional medicine in Turkey X. Folk medicine in Central Anatolia. Journal of Ethnopharmacology, 75, 95-115. https://doi. org/10.1016/S0378-8741(00)00399-8

Tetik, F., Civelek, S.., \& Çakılcıoğlu, U. (2013). Traditional uses of some medicinal plants in Malatya (Turkey). Journal of Ethnopharmacology, 146, 331-346. https://doi.org/10.1016/j.jep.2012.12.054

- Tugay, O., Ertuğrul, K., \& Yıldıztugay, E. (2005). Başarakavak (Konya) Kasabası Etnobotanik Alan Araştırması 2004. Türkiye Bilimler Akademisi Kültür Envanteri Dergisi, 4, 245-256. https://doi. org/10.22520/tubaked.2005.0010

Türkmen, Y. (2006). Kayseri şehir florası üzerine araştırma (Doctoral dissertation, Erciyes Üniversitesi, Kayseri). Retrieved from https:// tez.yok.gov.tr/UlusalTezMerkezi/tezSorguSonucYeni.jsp

Tuzlacı, E., \& Şenkardeş, İ. (2011). Turkish folk medicinal plants, X: Ürgüp (Nevşehir). Marmara Pharmaceutical Journal, 15, 58-68. https://doi.org/10.12991/201115432

Uzun, M., \& Kaya, A. (2016). An ethnobotanical research of medicinal plants in Mihalgazi (Eskişehir, Turkey). Pharmaceutical Biology, 54(12), 2922-2932. https://doi.org/10.1080/13880209.2016.1194 863 
- Vural, M., Karavelioğulları, F. A., \& Polat, H. (1997). Çiçekdağı (Kırşehir) ve çevresinin etnobotanik özellikleri. Ot Sistematik Botanik Dergisi, 4(1), 117-124.

- Yaşar, H. I., Koyuncu, O., Turan Koyuncu, F., \& Kuş, G. (2019). Sale of medicinal and aromatic plants and economic dimensions in Eskişehir herbalist. Research Journal of Biology Sciences, 12(2), 25-28.

- Yeşil, Y., \& Akalın, E. (2009). Folk medicinal plants in Kurecik area (Akçadağ/Malatya-Turkey). Turkish Journal of Pharmaceutical Sciences, 6(3), 207-220.

- Yeşilada, E. (2013). An Overview of Turkish Folk Medicine; Past and Present. Current Drug Delivery, 10, 1-4. https://doi. org/10.2174/1567201811310010015
Yeşilada, E., Honda, G., Sezik, E., Tabata, M., Fujita, T., Tanaka, T., ... Takaishi, Y. (1995). Traditional medicine in Turkey. V. Folk medicine in the inner Taurus Mountains. Journal of Ethnopharmacology, 46, 133-152. https://doi.org/10.1016/0378-8741(95)01241-5

Yeşilada, E., Honda, G., Sezik, E., Tabata, M., Goto, K., \& Ikeshiro, Y. (1993). Traditional medicine in Turkey IV. Folk medicine in the Mediterranean subdivision. Journal of Ethnopharmacology, 39, $31-38$. 